\title{
Muscle strength assessment among children and adolescents with growing pains and joint hypermobility
}

\author{
Avaliação da força muscular em crianças e adolescentes com dores de \\ crescimento e hipermobilidade articular
}

Marcolin ALV, Cardin SP, Magalhães CS

\begin{abstract}
Objective: To compare the muscle strength of children and adolescents with growing pains, with and without joint hypermobility, to healthy controls by means of quantitative tests. Method: Forty-seven children and adolescents were monitored because of growing pains: 24 with joint hypermobility (GP-JH group) and 23 without joint hypermobility (GP group). These cases, along with 47 healthy controls matched for age and gender, underwent two quantitative tests for muscle strength evaluation: the Childhood Myositis Assessment Scale (CMAS) and the Manual Muscle Strength Test (MMT). Anthropometric data such as height, weight, body mass index, triceps skinfold, mean arm circumference and arm muscle area were compared between the three groups. Results: The three groups did not present any statistical differences in anthropometric measurements. There were significant differences in median CMAS scores, which were lower in the GP (47; range 39-52) and GP-JH (46; range 40-51) groups than the control group (50; range 45-52; $p<0.0001$ ). Two of the timed CMAS exercises (head lift and leg lift duration) had significantly lower scores among the patients than among the controls $(p<0.0001)$. The median MMT scores in the GP (79; range 73-80) and GP-JH (78; range 32-80) groups were also significantly lower than the control group (80, range 78-80; $p<0.0001$ ). The best correlation between the CMAS and MMT scores was in the GP-JH group (Spearman $r=0.65, p=0.0007$ ). Application of CMAS and MMT on two occasions produced good agreement, with intraclass correlation coefficients of 0.87 (95\% Cl: 0.64-0.96; $p<0.0001$ ) and 0.92 ( $95 \% \mathrm{Cl}: 0.76-0.97 ; p<0.0001)$, respectively. Conclusion: Patients with growing pains, with and without joint hypermobility, presented mild to moderate muscle weakness, compared with healthy controls.
\end{abstract}

Key words: adolescents; children; muscle strength; pain; joint hypermobility.

\section{Resumo}

Objetivo: Avaliar, por meio de teste quantitativo, a força muscular em crianças e adolescentes com dores de crescimento, associada ou não com hipermobilidade articular e comparadas com controles saudáveis. Método: Quarenta e sete casos de crianças e adolescentes acompanhados por dores de crescimento, sendo 24 com hipermobilidade articular (DC-HA), 23 sem hipermobilidade articular (DC) e 47 controles saudáveis pareados por idade e gênero foram submetidos a dois testes quantitativos para a avaliação da força muscular, o Childhood Myositis Assessment Scale (CMAS) e o Manual Muscle Strength Test (MMT). Os dados antropométricos como altura, peso, índice de massa corporal, prega cutânea tricipital, circunferência média do braço e a área muscular do braço foram comparados entre os três grupos. Resultados: Os três grupos não apresentaram diferença estatística entre as medidas antropométricas. Houve diferença significante entre a mediana da pontuação do CMAS, sendo menores no grupo DC (47, mínimo e máximo 39-52) e DC-HA (46, mínimo e máximo 40-51), comparados com controles (50, mínimo e máximo 45-52; $p<0,0001)$. Dois dos exercícios cronometrados do CMAS, a elevação da cabeça e a duração da elevação das pernas, tiveram menor pontuação nos pacientes comparados aos controles ( $p<0.0001$ ). A pontuação mediana do MMT no grupo DC (79, mínimo e máximo 73-80) e DC-HA (78, mínimo e máximo 32-80) também apresentou diferença significante, sendo menor nos pacientes que nos controles (80, mínimo e máximo 78-80; p<0,0001). A melhor correlação entre a pontuação do CMAS e MMT foi no grupo DC-HA (Spearman r=0,65; $p=0,0007$ ). A aplicação do CMAS e MMT em duas ocasiões apresentou boa concordância e coeficiente de correlação intraclasse de 0,87 (IC 95\% 0,64-0,96; p<0,0001) e 0,92 (IC 95\% 0,76-0,97; $p<0,0001$ ), respectivamente. Conclusão: Os pacientes com dores de crescimento com ou sem hipermobilidade articular apresentaram fraqueza muscular de leve a moderada quando comparados com controles saudáveis.

Palavras-chave: adolescentes; crianças; força muscular; dor; hipermobilidade articular.

Recebido: 18/02/2008 - Revisado: 21/07/2008 - Aceito: 18/09/2008

Pediatric Rheumatology Unit, Department of Pediatrics, Botucatu Medical School, Universidade Estadual Paulista (UNESP), Botucatu (SP), Brazil Correspondence to: Claudia Saad Magalhães, Departamento de Pediatria - Faculdade de Medicina de Botucatu (UNESP) - Anexo D - Campus Rubião Junior, CEP 18618-970, Botucatu (SP), Brasil, e-mail: claudi@fmb.unesp.br 


\section{Introduction $: \therefore$.}

Limb pain, commonly referred to as "growing pains", is a common complaint in pediatric visits ${ }^{1}$. Growing pains typically occur among children aged 3-12 years and present a nonarticular intermittent pattern, with bilateral diffuse aches or pains in the legs at evening time. They are not associated with limping, limited mobility, local trauma or infections. Physical examinations, laboratory tests and imaging examinations give normal results; therefore growing pains are diagnosed by ruling out other alternatives. The reported prevalence ranges from 2.6 to $49.4 \%^{2}$. Because the pathogenesis of growing pains is unclear, many factors have been suggested, but no convincing evidence has been found ${ }^{3}$. Growing pains are not associated with serious organic disease, but frequent episodes may have a major impact on children and their families because of absence from school, daytime fatigue, reduced physical activity and frequent or chronic use of pain relief medication.

There have been increasing numbers of reports of persistent musculoskeletal pain among pediatric patients. Recent research has suggested there is a growing impact on activities of daily living and social functioning. The causes of growing pains are most frequently mechanical. Joint hypermobility, recurrent lower-limb arthralgia, anterior knee pain and back pain are increasingly recognized as "growing pains" ${ }^{\text {"3,4 }}$.

Children have an inherently greater range of motion in their joints than adults, and this gradually decreases with age. Hypermobility, as a phenomenon describing increased asymptomatic joint and spinal movements, has been reported in 2.3 to $30 \%$ of the cases in several previous studies ${ }^{4,5}$. Recently, it has been shown not to be such a benign condition that most children outgrow ${ }^{6}$. Limited physical activity, decreased physical fitness and lower bone mass have been reported in these children $^{6-9}$. Because some cases may present limitations on physical activity, planned intervention needs to be envisaged.

Joint hypermobility pain often appears after prolonged walking and playing, or even after typing or playing computer games. The most consistent precipitating factor is physical activity, which is almost invariably followed by exacerbated joint pain, thus resulting in a variable degree of functional impairment ${ }^{3,6,7}$. Pain amplification and lower pain threshold have been reported in individuals with abnormal physical activity levels ${ }^{6,10}$. Physical fitness has four components: muscle strength and endurance, flexibility, body composition and aerobic fitness. Aerobic fitness is most strongly associated with health benefits in the general population and it is the primary focus of most exercise programs. Although standard exercise prescriptions are not supported by evidence-based recommendations, stretching has been shown to modulate pain in a single controlled study ${ }^{11}$. Therefore, in addition to providing pain relief with analgesics and non-steroidal anti-inflammatory drugs, the main recommendation is to keep these children $\mathrm{fit}^{12}$.

Despite a growing body of research on musculoskeletal pain, there is no standard of care for prescribing physical activity to these children. Current data continue to support patient and parental education relating to gradual aerobic exercise, training in pain-coping strategies, stress-management skills and sleep hygiene education ${ }^{12}$. Many children may need support to break away from the vicious circle of inactivity, pain and unfitness. School-based physical education continues to be an accessible rehabilitative resource.

Since the children in the present study seemed to be unfit, we decided to address muscle strength assessment by means of quantitative non-instrumental measurements, as a reliable method for detecting muscle strength loss that could be applied in clinical practice without needing sophisticated equipment. There are other methods for measuring isokinetic strength in specific muscle groups, such as myometry, which specifically requires a handheld dynamometer and a trained examiner ${ }^{13}$. Among other non-instrumental tests, timed walking tests have also been used for assessing aerobic fitness among cases of chronic illnesses. High correlations have been found between walking distance and aerobic capacity with regard to pediatric cardiorespiratory diseases ${ }^{14}$ but not to musculoskeletal diseases. Such tests were considered to be poor predictors of aerobic fitness in cases of juvenile idiopathic arthritis ${ }^{15}$.

Two quantitative tests for assessing muscle strength in cases of muscle disease have recently been developed. The Childhood Myositis Assessment Scale (CMAS) was developed for juvenile dermatomyositis assessment and consists of a series of timed tasks that together test muscle strength, endurance and balance ${ }^{16}$. CMAS scoring correlates with the manual muscle strength test (MMT) for specific muscle groups, which is a test widely used for assessing muscle diseases ${ }^{17-19}$. Other diseases that may cause mild muscle weakness have not been addressed by using any of these tests.

The primary objective of the present study was to assess muscle strength among children and adolescents with growing pains, with and without joint hypermobility, and make comparisons with healthy controls. The secondary objective was to establish the relationship between the two scales for muscle strength measurements.

\section{Materials and methods $: \because 8$}

\section{Subjects}

Forty-seven patients and forty-seven healthy controls were recruited. The patients were consecutive, irrespective 
of age, and were all recruited during follow-up of complaints of recurrent musculoskeletal pain or arthralgia. They had previously been diagnosed with growing pains, underwent a complete diagnostic workout, and were assessed at the time of joining a physical activity program or physical education classes during the timeframe of this study. The exclusion criteria were the presence of pain, discomfort or analgesia use that could impair test performance, or any evidence of inflammatory joint disease. The cases were classified into two groups according to whether joint hypermobility was present: GP-JH group (with joint hypermobility) and GP group (without joint hypermobility). Beighton hypermobility scores of at least 4 out of 9 were used for joint hypermobility screening ${ }^{20}$.

Forty-seven volunteers who were attending physical education classes at community schools were invited to participate. The cases and controls trained or participated in school sports activities on average twice a week, but no formal survey of their specific activities was conducted.

The study protocol was approved by the Research Ethics Committee of our institution, Botucatu Medical School, Universidade Estadual Paulista (UNESP), under protocol number 434/2002. Written parental consent and patient assent, where appropriate, were obtained for all the research procedures.

\section{Procedures}

\section{Anthropometry}

The patients' and controls' heights, weights and body mass index (BMI) were determined using an electronic balance and wall-mounted stadiometer. Subcutaneous adiposity was measured by means of the triceps skinfold thickness using a Harpenden caliper. In addition, the arm circumference was measured according to standard procedures, in order to calculate the arm cross-sectional muscle area ${ }^{21}$ as an estimate of muscle mass, using international reference values for age and gender (Epi-Info 2002, CDC, USA).

\section{Muscle strength measurements}

The Childhood Myositis Assessment Scale (CMAS) consists of 14 ordinal items of motor performance: 1) head lift, 2) leg raise, 3) straight leg raise and lift duration, 4) moving from supine to prone, 5) sit-ups, 6) moving from supine to sit, 7) raise/straighten arm, 8) arm lift duration, 9) floor sit, 10) all fours with straight right leg, 11) floor rise, 12) chair rise, 13) stool step, and 14) pick up an object from the floor. This tool was designed to assess muscle function in cases of inflammatory muscle disease, with 14 maneuvers that were primarily chosen to assess proximal and axial muscle groups. All items are ranked according to the standard performance. The sum of all the items generates a composite score ranging from 0 to 52, with higher scores indicating better muscle function. The CMAS test was performed in accordance with the scoring instructions contained in a videotaped test performance that was kindly provided by the developers of this test ${ }^{16}$.

The manual muscle strength test (MMT) was performed in accordance with a modified Kendall scale ${ }^{17,18}$, using an ordinal scale from 0 to 10 points, on eight muscle groups: neck flexors, deltoids, biceps brachii, wrist extensors, gluteus maximus, gluteus medius, quadriceps and ankle dorsiflexors. This yielded a composite score ranging from 0 to 80 , with higher scores indicating better muscle strength. It was performed unilaterally, on the right side.

The text for the adapted instruments had previously been validated in a multicenter international study ${ }^{19}$, and the respective instructions for performing the test are presented in Appendix 1. All measurements and tests were conducted in a standard consultation room using a precision stopwatch for the timed tasks, such as head lift, leg lift and arm lift duration. The MMT and CMAS tests were performed sequentially in the same session by a single assessor. The clinical assessment was conducted independently by two other assessors. The demographic data, diagnosis, joint complaints, hypermobility scores and treatment data were all recorded during the same visit.

All the subjects underwent a cross-sectional evaluation. Thirteen unselected cases underwent another test on a different occasion. Only the first test was used for group comparisons.

The method for identifying hypermobility was the Beighton nine-point scoring system for the following maneuvers: passive extension of the fifth metacarpophalangeal joint to $\geq 90^{\circ}$, opposition of the thumb to the volar side of the ipsilateral forearm, hyperextension of the elbow $\geq 10^{\circ}$, hyperextension of the knee $\geq 10^{\circ}$ and placing both hands flat on the floor without bending the knees. In maneuvers 1-4, one point was given for each side of the body, with a maximum of nine points. An arbitrary number of four or more out of nine was considered to show generalized hypermobility ${ }^{20}$.

\section{Statistical Analysis}

The descriptive statistics for continuous variables consisted of the median and range. Group comparisons were performed using the nonparametric Kruskal-Wallis test, followed by the multiple-comparisons post-test. Spearman's rank correlation test was used to assess the relationship between variables of related constructs. Correlation coefficients between 0.26 and 0.49 were considered poor; between 0.50 and 0.69, moderate; and greater than 0.7, high agreement. The intra-rater agreement was obtained by means of the intraclass correlation coefficient. GraphPad Prism 4.0 and SPSS 
12.0 were the software used for the statistical analysis. Statistical significance was set at $\mathrm{p} \leq 0.05$.

\section{Results $: \because$.}

\section{Anthropometric measurements}

There were no statistical differences in demographic, clinical or anthropometric measurements among the three groups (Table 1).

\section{The Childhood Myositis Assessment Scale (CMAS)}

The median CMAS score in the GP group was 47 (minimum 39; maximum 52), and in the GP-JH group it was 46 (minimum 40; maximum 51). There was a significant difference in comparison with the score for the controls (median 50; minimum 45; maximum 52) according to the Kruskal-Wallis test ( $\mathrm{p}<0.0001)$. Post-test multiple comparison indicated significant differences for both the GP and the GP-JH groups compared with the control group, but no difference between them.

CMAS head lift and leg lift duration in the GP and GP-JH groups, expressed in seconds (0-120) rather than as an ordinal 0-5 scale, were both significantly different from healthy controls $(p<0.0001)$. No significant difference was found in comparing arm raise duration (0-60 seconds) and number of sit-ups (0-6) among the three groups (Table 2).

\section{Manual muscle strength testing (MMT)}

The median MMT (0-80) in GP was 79 (minimum 73; maximum 80) and in GP-JH it was 78 (minimum 32; maximum 80). These were significantly different from the controls (median 80; minimum 78; maximum 80; Kruskal-Wallis test, $\mathrm{p}<0.0001$ ). Post-test multiple comparison indicated significant differences for both GP and GP-JH in comparison with the controls but no difference between them (Table 2).

\section{MMT and CMAS correlation}

The correlation between CMAS and MMT scoring was moderate in the GP-JH group, $(r=0.65 ; \mathrm{p}=0.0007)$, but weak in the control group $(\mathrm{r}=0.31 ; \mathrm{p}=0.03)$, and non-significant in the GP group. MMT scoring showed moderate correlation with age $(\mathrm{r}=0.59 ; \mathrm{p}<0.0001)$, but weak correlation with arm crosssectional muscle area $(\mathrm{r}=0.41 ; \mathrm{p}<0.0001)$.

\section{Retesting}

MMT and CMAS retesting within 13-27 days resulted in good intra-rater agreement according to the intra-class correlation coefficient, which was 0.87 (95\% CI: 0.64-0.96) for CMAS and 0.92 (95\% CI: 0.76-0.97) for MMT.

\section{Discussion $: \because:$}

Patients with growing pains, both with and without joint hypermobility, presented lower quantitative muscle strength scores than healthy controls. This has not been reported previously, especially because both of the tests used were developed for assessing muscle strength in cases of muscle diseases, and not growing pains and hypermobility. The widely used MMT (Appendix) has some limitations when used on children under five years of age. MMT accuracy is dependent on examiner strength, which limits the detection of moderate weakness to manual resistance. Clinicians using manual testing should determine their own maximal vertical push force and the extent to which they can detect weakness. It seems less sensitive to lesser degrees of muscle weakness. CMAS (Appendix) requires a trained observer to monitor a series of well-known exercises linked to daily activities like sitting, standing, bending, kneeling and performing sit-ups. It therefore reflects more function with better motivation for younger ages. Interestingly, the correlation between MMT and CMAS was not as high as seen in cases

Table 1. Demographic and anthropometric data on patients and controls.

\begin{tabular}{|c|c|c|c|}
\hline Groups & $\begin{array}{c}\mathrm{GP} \\
\mathrm{n}=23\end{array}$ & $\begin{array}{c}\text { GP-JH } \\
n=24\end{array}$ & $\begin{array}{c}\text { Control } \\
n=47\end{array}$ \\
\hline Age (y) & $10.2(4.1-14.1)$ & $9.3(4.4-14.5)$ & $9.4(6.5-14.3)$ \\
\hline Gender M:F & $12: 11$ & $8: 16$ & $23: 24$ \\
\hline Height (cm) & $134(98-161)$ & $129(107-161)$ & $134(114-173)$ \\
\hline Weight (kg) & $33.8(14.2-50.7)$ & $27.2(16.9-65.1)$ & $30.3(21-55.7)$ \\
\hline Body mass index $\left(\mathrm{kg} / \mathrm{m}^{2}\right)$ & $16.9(13.8-29.5)$ & $16.7(14-26.2)$ & $16.1(13.5-25.3)$ \\
\hline Arm circumference $(\mathrm{cm})$ & $21(15-30)$ & $20(15.5-29.5)$ & $19.5(16-28)$ \\
\hline Triceps skinfold (mm) & $9(5-26)$ & $10(4-25)$ & $9(5-22)$ \\
\hline Arm cross sectional muscle area $\left(\mathrm{cm}^{2}\right)$ & $27(14-42)$ & $22(15-38)$ & $23(14-39)$ \\
\hline
\end{tabular}

Median (minimum - maximum), GP: Growing pains, GP-JH: Growing pains and joint hypermobility. 
Table 2. Manual Muscle Test (MMT) and Childhood Myositis Assessment Scale (CMAS) overall scores and timed tasks for patients and controls.

\begin{tabular}{lccc} 
Tests & $\begin{array}{c}\text { GP } \\
\mathrm{n}=23\end{array}$ & $\begin{array}{c}\text { GP-JH } \\
\mathrm{n}=24\end{array}$ & $\begin{array}{c}\text { Control } \\
\mathrm{N}=47\end{array}$ \\
\hline CMAS $(0-52)$ & $47(39-52)^{\star}$ & $46(40-51)^{\star}$ & $50(45-52)$ \\
\hline Head lift duration $(0-120 \mathrm{sec})$ & $26(5-120)^{\star}$ & $23(1-120)^{\star}$ & $73(12-120)$ \\
\hline Leg lift duration $(0-120 \mathrm{sec})$ & $59(10-120)^{\star}$ & $40(12-120)^{\star}$ & $120(28-120)$ \\
\hline Arm lift duration $(0-60 \mathrm{sec})$ & $60(29-63)$ & $60(20-62)$ & $60(60-62)$ \\
\hline Number of sit-ups $(0-6)$ & $6(2-6)$ & $6(2-6)$ & $6(2-6)$ \\
\hline MMT $(0-80)$ & $79(73-80)^{\star}$ & $78(32-80)^{\star}$ & $80(78-80)$ \\
\hline
\end{tabular}

Median (minimum - maximum), ${ }^{*} p<0.0001$ for GP vs. control and GP-JH vs. control, GP: Growing pains, GP-JH: Growing pains and joint hypermobility.

of inflammatory muscle diseas $\mathrm{e}^{22}$ in which variable degrees of muscle weakness occur. As well as muscle strength, some CMAS tasks also assess coordination and balance. Poor coordination and balance have been described in cases of joint hypermobility ${ }^{23}$, but no significant differences were found between the groups with and without joint hypermobility, as screened by the Beighton score $e^{20,24}$.

Another limitation on our study was the influence of age and gender that has been described recently, with normative data for nine of the 14 CMAS maneuvers ${ }^{25}$. Although we paired subjects by age, we did not do so for gender because this sample was obtained by means of consecutive inclusion, to give a convenience sample. There was no major discrepancy in body composition. A broad age range was included and the number of patients did not allow age stratification. We also observed that the timed tasks accounted for the difference, as reported in normative data development ${ }^{25}$. For both tests, there was good intra-rater agreement. Both of these tests are intended for longitudinal assessments, to monitor improvement or worsening, and from a practical viewpoint, they could be of interest to the area of physical therapy with regard to planning and assessing interventions for such children.

We therefore concluded that these tests could be valuable for longitudinal assessments of responses to physical activity and exercises for muscle strengthening, considering that pediatric patients with growing pains, with and without joint hypermobility, presented mild to moderate muscle weakness, compared with healthy controls.

\section{References : : :}

1. De Inocencio J. Epidemiology of musculoskeletal pain in primary care. Arch Dis Child. 2004;89:431-4.

2. Goodyear-Smith F, Arrol B. Growing pains. BMJ. 2006;333:456-7.

3. Uziel Y, Hashkes PJ. Growing pains in children. Pediatr Rheumatol Online J. 2007;5:5

4. Murray KJ. Hypermobility disorders in children and adolescents. Best Pract Res Clin Rheumatol. 2006;20(2):329-51.

5. Forleo LHA, Hilario MO, Peixoto AL, Naspitz C, Goldenberg J. Articular hypermobility in school children in São Paulo, Brazil. J Rheumatol. 1993;20(5):916-7.

6. Adib N, Davies K, Grahame R, Woo P, Murray K. Joint hypermobility syndrome in childhood. A not so benign multisystem disorder? Rheumatology. 2005;44(6):744-50.

7. Ruperto N, Malattia C, Bartoli M, Trail L, Pistorio A, Martini A, et al. Functional ability and physical and psychosocial well-being of hypermobile school children. Clin Exp Rheumatol. 2004;22(4):495-8.

8. Roberto AM, Terreri MT, Szejnfeld V, Hilario MO. Bone mineral density in children. Association with musculoskeletal pain and/or joint hypermobility. J Pediatr (Rio J). 2002;78(6):523-8.

9. Friedland O, Hashkes PJ, Jaber L, Cohen HA, Eliakim A, Wolach B, et al. Decreased bone speed of sound in children with growing pains as measured by quantitative ultrasound. J Rheumatol. 2005;32(7):1354-7.
10. Hashkes P, Friedland O, Jaber L, Cohen A, Wolach B, Uziel Y. Children with growing pains have decreased pain threshold. J Rheumatol. 2004;31(3):610-3.

11. Baxter MP, Dulberg C. "Growing pains" in childhood: a proposal for treatment. J Pediatr Orthop. 1988;8(4):402-6.

12. Kerr A, Macmillan CE, Uttley WS, Luqmani RA. Physiotherapy for children with hypermobility syndrome. Physiotherapy. 2000;86(6):313-7.

13. Maillard SM, Jones R, Owens CM, Pilkington C, Woo PM, Wedderburn $L R$, et al. Quantitative assessments of the effects of a single exercise session on muscles in juvenile dermatomyositis. Arthritis Rheum. 2005;53(4):558-64.

14. Nixon PA, Josiwiak ML, Fricker FJ. A six minute walk test for assessing exercise tolerance in severely ill children. J Pediatr. 1996;129(3):362-6.

15. Lellieveld OT, Takken T, Van der Net J, van Weert E. Validity of the 6-minute walking test in juvenile idiopathic arthritis. Arthritis Rheum. 2005;53(2):304-7.

16. Lovell DJ, Lindsley CB, Rennebohm RM, Ballinger SH, Bowyer SL, Giannini EH, et al. Development of validated disease activity and damage indices for the juvenile idiopathic inflammatory myopathies. II. The Childhood Myositis Assessment Scale (CMAS): a quantitative tool for the evaluation of muscle function. The Juvenile Dermatomyositis Disease Activity Collaborative Study Group. Arthritis Rheum 1999;42(10):2213-9. 
17. Hicks J, Wesley R, Koziol D, Smith M, Jain M, Cintas H, et al. Validation of manual muscle testing (MMT) in the assessment of juvenile dermatomyositis (JDM). Arthritis Rheum. 2000;43(Suppl):S194.

18. Florence JM, Pandya S, King WM, Robison JD, Baty J, Miller JP, et al. Intrarater reliability of manual muscle test (Medical Research Council Scale) grades in Duchenne's muscular dystrophy. Phys Ther. 1992;72(2):115-22.

19. Ruperto N, Ravelli A, Pistorio A, Ferriani V, Calvo I, Ganser G, et al. The provisional Paediatric Rheumatology International Trials Organisation/American College of Rheumatology/European League Against Rheumatism disease activity core set for evaluation of response to therapy in Juvenile Dermatomyositis; a prospective validation study. Arthritis Rheum. 2008;59(1):4-13.

20. Hakim A, Grahame R. Joint hypermobility. Best Pract Res Clin Rheumatol. 2003;17(6):989-1004.
21. Frisancho AR. New norms of upper limb fat and muscle areas for assessment of nutritional status. Am J Clin Nutr. 1981;34(11):2540-5.

22. Huber AM, Feldman BM, Rennebohm RM, Hicks JE, Lindsley CB, Perez MD, et al. Validation and clinical significance of the childhood myositis assessment scale for assessment of muscle function in the juvenile idiopathic inflammatory myopathies. Arthritis Rheum. 2004;50(5):1595-603.

23. Tirosh E, Jaffe M, Marmur R, Taub Y, Rosenberg Z Prognosis of motor development and joint hypermobility. Arch Dis Child. 1991;66(8):931-3.

24. Grahame R. The need to take a fresh look at criteria for hypermobility. J Rheumatol. 2007;34(4):664-5.

25. Rennebohm RM, Jones K, Huber A, Ballinger SH, Bowyer SL, Feldman $\mathrm{BM}$ et al. Normal scores for nine manoeuvers of the childhood myositis assessment scale. Arthritis Rheum. 2004;51(3): 365-70.

\section{Appendix 1}

Padronização dos comandos para o teste de avaliação da força muscular manual (MMT) para crianças e adolescentes

A avaliação da força muscular é registrada em folha de exame e as instruções detalhadas sobre os comandos, visando uniformizar a técnica e a pontuação.

...."QUEREMOS VER SE VOCE ESTÁ FORTE DE VERDADE! Quando eu disser para você segurar e não deixar que eu te empurre, tente segurar com força para não me deixar vencer. Você tem que ser forte como um 'power ranger' (pode ser sugerido qualquer herói nacional ou personagem popular, veja 0 que cai bem para motivar os seus pacientes).

1. Flexores do Pescoço: (Deitado de costas) Levante a sua cabeça acima da mesa e segure. E agora segure firme enquanto eu empurro sua cabeça para baixo, não deixe baixar a cabeça e segure o mais forte que puder.

2. Deltóide Médio: Segure o seu braço para cima (demonstre), e eu vou empurrar para abaixar o seu braço. Não deixe cair, segure o mais forte que puder.

3. Bíceps Braquial: 'Vamos brincar de braço de ferro/ quebra de braço', (flexione o cotovelo para demonstrar). Dobre (flexione) o cotovelo e me impeça de puxar para baixo, segure firme e não me deixe abaixar 0 seu braço.
4. Extensores dos Punhos: Estenda completamente os punhos mantendo a posição enquanto eu tento puxar a sua mão para baixo, não deixe que eu abaixe a sua mão. Mostre a sua força.

5. Gluteus Maximus: Deite de barriga para baixo e dobre os joelhos. Agora tente elevar a perna toda para cima (demonstre passivamente). Segure-a nesta posição, enquanto eu tento empurrá-la para baixo. Segure firme e não me deixe empurrar.

6. Gluteus Medius: Você pode deitar-se de lado (esquerdo)? Agora você consegue levantar a perna mantendo os joelhos completamente estendidos? Agora segure firme a perna no ar enquanto eu tento empurrar a sua perna para baixo. Segure firme e com muita força.

7. Quadriceps: Sentado com apoio, chute a perna para 0 alto e a mantenha elevada com os joelhos estendidos. Segure firme nesta posição enquanto eu tento abaixar e dobrar o seu joelho. Seja forte e mantenha a perna estendida no ar.

8. Dorsiflexores dos Tornozelos: Dobre (Flexione) o seu pé para cima (demonstre) e segure-o enquanto eu tento empurrá-Io para baixo. Não me deixe empurrá-Io para baixo. 